\title{
Water and Hydropower in the Green Economy and Sustainable Development of the Hindu Kush-Himalayan Region
}

\section{Ramesh Vaidya}

\begin{abstract}
Water storage projects in the Himalayan region are thought of primarily in the context of hydropower generation, which can be perceived as an opportunity driven approach. However, water scarcity is a major problem in the basins of the ten rivers originating in the region, especially in the dry season. This is due to high intra-annual rainfall variability, which may get worse due to population growth and climate change and variability. Water storage projects may, therefore, have to be thought of in the context of water scarcity, which can be perceived as a challenge driven approach for water storage capacity development. This paper suggests that to increase the pace of development of constructed storage systems such as large multi-purpose projects that provide water availability as well as hydroelectric power benefits, institutional mechanisms may have to be crafted for benefit-sharing between upstream and downstream communities affected by storage projects. Until that time, it may be necessary to increase the pace of hydropower development in the region through small- and medium-size hydropower projects. This paper discusses the economic, environmental, technological, financial, and institutional barriers to the development of small hydroelectric power plants in the region. It also discusses the role of the Payment for Ecosystem Services (PES) and raising carbon finance under the Clean Development Mechanism (CDM) as potential solutions to partially overcome environmental and financial barriers respectively.
\end{abstract}

Key words: Hydropower, green economy, sustainable development, payment for environmental services, carbon finance, Himalaya-Hindu Kush (HKH) region

\section{Introduction}

The United Nations Environment Program (UNEP) has defined a 'green economy' as one that results in improved wellbeing and social equity, while significantly reducing environmental risks and ecological scarcities (UNEP 2011). ICIMOD and UNEP have felt the need to elaborate on this concept in the context of mountain regions, to the extent that mountains provide ecosystem goods and services conducive to the development of a green economy.

Mountains are the Earth's natural freshwater reservoirs. They store an immense amount of water and gradually release it to support lives and livelihoods downstream. The Hindu Kush-Himalayan (HKH) region has one of the largest bodies of ice outside the polar caps, covering more than 33,000 km² (Dyurgerov and Meier 2005). These glaciers, ice fields, and snow packs provide important intra- and inter-annual water storage facilities. The Himalayan mountains are referred to as the 'water towers' of Asia and are vital to the 1.3 billion people living in the basins of the ten rivers originating in the $\mathrm{HKH}$ region. According to the typology developed in the Millennium Ecosystem Assessment (MA 2005), the mountain ecosystems of the $\mathrm{HKH}$ provide a number of water-related ecosystem goods and services, including:

- provisioning services such as freshwater and hydropower,

- regulating services such as flood regulation and water purification, and

- cultural services such as those provided by religious sites.

This paper focuses on the provisioning service of hydropower.

Historically, discussions on water-related ecosystem services in the $\mathrm{HKH}$ region have emphasized the tremendous potential for hydropower generation as a missed opportunity. However, the major problem in the region is water scarcity in the dry season as a result of high intra-annual variability of precipitation. This problem has been exacerbated in recent times by a number of drivers of change including population growth, urbanization, climate change, and climate variability.

To place these opportunities and challenges in the proper context, Section-II of this paper looks at the water availability and energy security in the context of water-energy nexus in the HKH countries. SectionIII looks at the structure of the hydropower industry in the $\mathrm{HKH}$ countries, the constraints on harnessing water resources to achieve the region's hydropower potential, and payment for environmental services (PES) as a solution to the environmental constraints on hydropower development. It also discusses the potential for raising carbon finance under the Clean Development Mechanism (CDM) as a source of funding to overcome financial constraints on the industry. In Section-IV, knowledge gaps in the implementation of these solutions are discussed. Section-V concludes by drawing some policy implications from the discussion on water and hydropower.

\section{Water-Energy Nexus Energy security}

The HKH mountain systems have the potential to play a vital role in energy security in the region. The hydropower potential in the region conservatively exceeds 500 GW (Table 1). If properly harnessed, hydropower could play a crucial role in transforming the lives of the 1.3 billion people living in the river basins of the $\mathrm{HKH}$ mountains. It is, therefore, quite natural for Bhutan, Nepal, and the Indian HKH states to highlight the hydropower potential in the region, often 
in the context of an appeal for regional cooperation for a holistic approach to water resources development.

"Tremendous opportunities are available for sub-regional cooperation... among the countries in the Ganges-Brahmaputra-Meghna basin. ... Development efforts in water resources, for example, would help irrigate the fertile fields in the plains of India, improve the waterways so vital for the transportation sector of Bangladesh, and generate hydropower in Nepal to meet the energy needs of the region as a whole. Such a development strategy may be the key to future prosperity in the region." (UN General Assembly Statement delivered by the Late Honorable Madame Shailaja Acharya, Deputy Prime Minister of Nepal, 1998).
India receives almost $50 \%$ of its annual rainfall in just 15 days (Economist 2010). This is primarily due to the high intra-annual rainfall variability in the region. The relative variability, measured by the coefficient of variation (the ratio between the standard deviation and the mean) is about $100 \%$ for six of the countries in the region (Afghanistan, Bangladesh, Bhutan, India, Myanmar, and Nepal). The Democratic People's Republic of Korea and Mongolia are the only other two countries in Asia with such high intra-annual rainfall variability (Figure 1). When the consequences of climate change, population growth, and economic development are superimposed on the high degree of intra-annual rainfall variability, it is clear that the threat of water scarcity poses a serious challenge to the people living in the ten river basins of the HKH mountains. A critical

\begin{tabular}{|c|c|c|c|c|c|}
\hline Country & $\begin{array}{c}\text { Carbon Dioxide } \\
\text { Emissions, } 2004 \\
\text { ('000 tons) }\end{array}$ & $\begin{array}{l}\text { Actual Installed } \\
\text { Hydropower } \\
\text { Capacity }\end{array}$ & $\begin{array}{l}\text { Hydropower } \\
\text { Potential (MW) }\end{array}$ & $\begin{array}{c}\text { Access to } \\
\text { Electricity, } 2005(\%)\end{array}$ & $\begin{array}{l}\text { Per Capita Electric Power } \\
\text { Consumption, } 2008 \text { (kWh) }\end{array}$ \\
\hline Afghanistan: & 693 & NA & NA & 7 & NA \\
\hline Bangladesh: & 37,165 & NA & Not significant & 32 & 208 \\
\hline Bhutan: & 414 & $1,465 a$ & $23,760^{a}$ & NA & NA \\
\hline China: & $5,010,170$ & NA & $272,000^{b}$ & 99 & 2,455 \\
\hline India: & $1,342,962$ & $24,630^{\mathrm{c}}$ & $114,398^{c}$ & 56 & 566 \\
\hline Myanmar: & 9,760 & NA & NA & 11 & 97 \\
\hline Nepal: & 3,043 & 658 & 42,130 & 33 & 89 \\
\hline Pakistan: & 125,669 & 6,608 & 46,000 & 54 & 436 \\
\hline \multicolumn{6}{|c|}{$\begin{array}{l}\text { Data for Bhutan do not include projects with a capacity of less than } 10 \mathrm{MW} \text {. } \\
\text { Data for China are for the Himalayan provinces of the Tibetan Autonomous Region, Qinghai, Sichuan, and Yunnan. } \\
\text { Data for India are for the Himalayan states of Jammu and Kashmir, Himachal Pradesh, Uttaranchal, and NE India. Data for India } \\
\text { do not include projects with a capacity of less than } 25 \mathrm{MW} \text { for projects completed after } 2003 \text { or projects with a capacity of } \\
\text { less than } 3 \mathrm{MW} \text { for projects completed before } 2003 \text {. }\end{array}$} \\
\hline
\end{tabular}

Table 1. Carbon dioxide Emissions and Hydropower Potential in the HKH Countries (sources: Asian Development Bank, Basic Statistics, 2009; data.worldbank.org/indicators; earthtrends.wri.org; PTC India; Chinese Government Statistical Bureau; CEA 2008; WECS 2002 and the Nepal Electricity Authority; Bhutto and Karim 2007)

At present, only about half of the population in the HKH countries has access to electricity (with the exception of China). With increasing levels of industrialisation, the level of electric power consumption will increase. Hydropower generated by the HKH mountain systems could be a low-carbon alternative to fossil fuel-based electricity generation to meet electricity demand in the future. This is especially important for the $\mathrm{HKH}$ countries, as some have high levels of carbon dioxide emissions, although their per capita emission levels are low (Table 1).

\section{Water Availability}

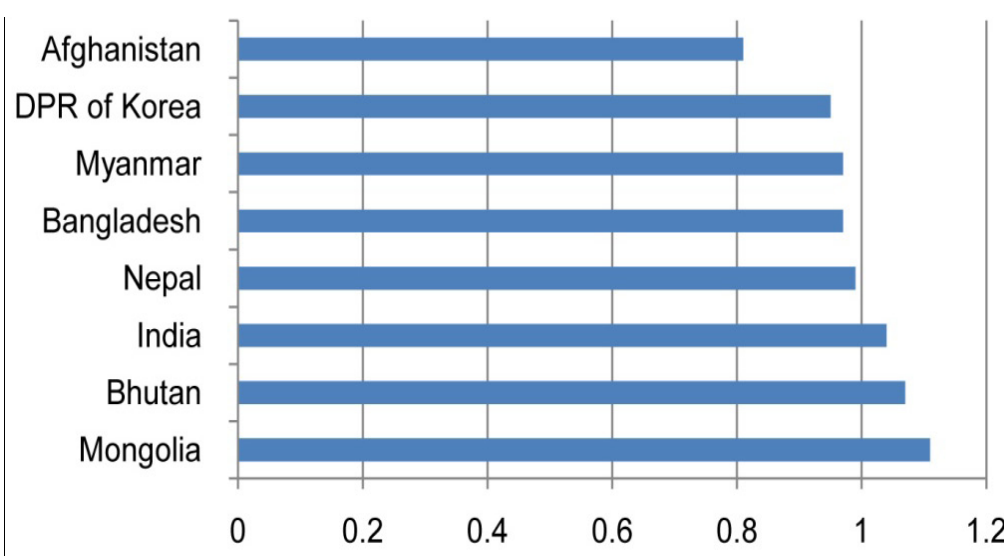
mountain Centre for Climate Change Research (source: Mitchell, TD; Hulme, M: systems play a vital role in providing food New, M (2002) Climate Data for Political Areas. Area 34. 109-112) security and potential energy security, and in maintaining environmental flow issue is how to store the massive quantities of rain that fall in a very requirements, water availability in the dry short period for use over the entire year.

season is a serious problem. For example,

A study published in the journal Science projected that as a result 
of population growth and economic development the relative change in the ratio of water demand (measured by annual water withdrawal or use in domestic, industrial and irrigated agriculture sectors) to water supply (measured by mean annual surface and subsurface runoff accumulate as river discharge) will increase in 2025 by more than $20 \%$, compared to the baseline index of 1985, in South Asia, South East Asia, Central Asia, and the south-eastern region of China (Vorosmarty et al 2000).

In a more recent study, also published in Science, Immerzeel, van Beek and Bierkens (2010) argue that while melt water plays only a modest role in the flows of the Ganges, Yangtze, and Yellow rivers, it is extremely important in the Indus basin and important in the Brahmaputra basin, and therefore climate change effects on water availability in these two basins are likely to be severe. The study notes, however, that water availability is also a problem in the other basins in the dry season. Further, although the Fourth Assessment Report of the Intergovernmental Panel on Climate Change (IPCC 2007) suggests that the current trends of glacier melt and potential climate change may cause these five rivers to be seasonal rivers, the Immerzeel, van Beek and Bierkens (2010) study argues that these rivers are already seasonal because the period of increased melt water and the monsoon season coincide, and water shortages are traditionally a problem in the other months.

Fortunately, except for Afghanistan, based on the Tyndall Centre data for 2005, the countries of the $\mathrm{HKH}$ have relatively high mean annual rainfall and low interannual rainfall variability. As a result, it may be possible to develop solutions to the water scarcity problem. To this end, there is a need to look at water storage capacity development and pursue a challenge-driven approach to find appropriate solutions.

\section{Hydropower Development: Constraints and Solutions Structure of Industry}

Although water storage in the HKH region is largely thought of in the context of hydropower development, the countries in the region have chosen to build a large number of run-of-the-river systems, instead of storage systems. The main concern about hydropower in the region is that run-of-the-river hydropower projects result in a long period of brown-outs during dry season. Daily pondage type systems may offer a solution at a reasonable cost, without having to build larger storage reservoirs (WECS 2002). Although the mix of power plants in the system may be an issue, the main issue is how to overcome the constraints to improve the pace of hydropower development in the region.

On the demand side, per capita commercial energy consumption in the $\mathrm{HKH}$ countries is much lower than the world average. However, even at current levels of energy consumption, there is room for substituting commercial for the non-commercial energy, and hydro energy may be an appropriate form of commercial energy for the region. There is also room to supply energy to the industrial belts of the newly industrialised countries in the region, assuming transmission networks and transboundary power exchange issues can be managed.

On the supply side, the hydro energy potential of the HKH region is more than $500 \mathrm{GW}$. However, the actual capacity harnessed so far is much less (see Table 1). Even at the current level of demand per capita for electricity, the gap between supply and demand is high. If the potential is so favourable, then what are the constraints on the development of the hydroelectric power industry in region?

As the issues involved in the development of large hydro projects are different from those of small and medium size projects, in the context of green economy, it is better to look at the structure of the hydroelectric power industry in the region with a focus on small and medium hydropower plants. This section looks at the structure of the hydropower industry in different countries in the region.

\section{Total Installed Capacity.}

In terms of the total installed capacity, China has 30,000 MW of installed capacity in small power plants - the highest of all the HKH countries. This is almost a quarter of China's potential capacity for small power plants. About a third of China's counties rely on such power plants as their main source of electricity. It is expected that from 2020 to 2030 an additional 70,000 MW of capacity will be added, resulting in a total small hydropower capacity of 100,000 MW, which will be about $10 \%$ of the country's total installed power capacity at that time (Jiang 2006). As at 2010, China had reportedly built 45,000 small hydropower plants (less than 50 MW capacity) with a total installed capacity of over 55,000 MW (Liu and Hu 2011). China clearly has rich experience in this area.

One of the major reasons for the success of small hydropower plants in China is the high level of electricity consumption for industrial activities in the rural areas. Data for 1992 on the demand for power from mini- and micro-hydro plants (up to $500 \mathrm{~kW}$ capacity) shows that $79 \%$ of the energy produced by these plants was used by rural industries, including agro-processing activities, while about $6 \%$ was used for irrigation and $13 \%$ for lighting (ICIMOD 1994).

\section{Diversity in Structure.}

Nepal's hydropower industry has a more diverse structure, and Nepal has good experience in the private financing of power projects (Table 2). All of the power plants currently in operation in Nepal are small (25 MW capacity or below) and medium (above $25 \mathrm{MW}$, but at or below $300 \mathrm{MW}$ capacity). Twenty-eight\% of installed capacity comes from plants with a capacity of $25 \mathrm{MW}$ or below and $72 \%$ from pants with a capacity of above $25 \mathrm{MW}$ but 
below $300 \mathrm{MW}$. They operate under private $(28 \%$ of the installed capacity) and public ownership (72\%). While the majority of the plants are gridconnected ( $97 \%$ of the installed capacity), some are isolated, especially privately-owned communitybased micro-power plants of less than $100 \mathrm{~kW}$ capacity.

\section{Power Trading}

Bhutan and India have experience in the trading of power. India intends to use its recent domestic experience in regional grid interconnections to expand to cross-border grid interconnections. India's major remote mountain valleys of Gilgit, Baltistan, and Chitral in northern Pakistan, micro-hydropower plants (150 $\mathrm{kW}$ or less) were introduced in 1990 as a communityled development initiative by the Aga Khan Rural Support Program. By 2005, these communities had built 240 such plants with a total capacity of more than 10,000 kW. A Clean Development Mechanism (CDM) project was registered with the CDM Executive Board in October 2009 to develop 103 new micro and mini hydropower plants in Pakistan with a total capacity of $15 \mathrm{MW}$ at a cost of US $\$ 18$ million. The project expects to raise carbon finance of about US $\$ 5.7$ million in the first seven years, which will help fund the payments

\begin{tabular}{|c|c|c|c|c|c|c|c|}
\hline $\begin{array}{l}\text { INSTALLED } \\
\text { CAPACITY OF } \\
\text { POWER PLANT }\end{array}$ & $\begin{array}{l}\text { State Ownership, } \\
\text { National Grid }\end{array}$ & $\begin{array}{c}\text { Private } \\
\text { Ownership, } \\
\text { National Grid }\end{array}$ & $\begin{array}{c}\text { State } \\
\text { Ownership, } \\
\text { Isolated }\end{array}$ & $\begin{array}{l}\text { Private } \\
\text { Ownership, } \\
\text { Isolated }\end{array}$ & $\begin{array}{l}\text { Total, } \\
\text { National } \\
\text { Grid }\end{array}$ & $\begin{array}{c}\text { Total, } \\
\text { Isolated }\end{array}$ & Total \\
\hline Up to $100 \mathrm{~kW}$ & & & $\begin{array}{l}1.75^{\mathrm{a}} \text { (3 plants; } \\
2 \text { leased to } \\
\text { private sector) }\end{array}$ & 13.87 & & 15.62 & 15.62 \\
\hline $100 \mathrm{~kW}$ to $1 \mathrm{MW}$ & $\begin{array}{c}3.2^{\mathrm{a}}(15 \text { plants, } \\
\text { including a } 1 \mathrm{MW} \text { plant } \\
\text { and a } 640 \mathrm{~kW} \text { plant })^{\mathrm{b}}\end{array}$ & 6.6 (9 plants) & $\begin{array}{c}2^{\mathrm{a}} \\
\text { (15 plants) }\end{array}$ & $\begin{array}{c}1 \\
\text { (2 plants) }\end{array}$ & 9.8 & 3 & 12.8 \\
\hline $1 \mathrm{MW}+$ to $5 \mathrm{MW}$ & 10.1 (5 plants) & $\begin{array}{l}17.6(7 \\
\text { plants })\end{array}$ & & & 27.7 & & 27.7 \\
\hline $5 \mathrm{MW}+$ to $10 \mathrm{MW}$ & 6.2 (1 plant) & $\begin{array}{l}12.6(2 \\
\text { plants })\end{array}$ & & & 18.8 & & 18.8 \\
\hline $10 \mathrm{MW}+$ to $25 \mathrm{MW}$ & 78 (5 plants) & 34 (2 plants) & & & 112 & & 112 \\
\hline $25 \mathrm{MW}+$ to $50 \mathrm{MW}$ & 32 (1 plant) & 36 (1 plant) & & & 68 & & 68 \\
\hline $50 \mathrm{MW}+$ to $100 \mathrm{MW}$ & 199 (3 plants) & 60 (1 plant) & & & 259 & & 259 \\
\hline $100 \mathrm{MW}+$ to $150 \mathrm{MW}$ & 144 (1 plant) & & & & 144 & & 144 \\
\hline Totals: & 472.5 (31 plants) & $\begin{array}{l}166.8(22 \\
\text { plants })\end{array}$ & $\begin{array}{l}3.75(18 \\
\text { plants) }\end{array}$ & $14.87 \mathrm{MW}$ & 639.3 & 18.62 & 657.92 \\
\hline
\end{tabular}

Table 2. Installed Capacity of Small and Medium Hydropower Plants in Nepal, 2010 (MW) (source: NEA 2010)

cross-border interconnections are with Bhutan: the Chukha Hydroelectric Project (336 MW) interconnected at Birpara in India and the Tala Project (1,020 MW) at Silguri in India. Annual power trading revenue to Bhutan from the Chukha plant is about US $\$ 48$ million and from the 60 MW Kurichhu plant is about US\$10 million (Sen 2006). During FY2009/10, the total power imported from Bhutan's Chukha, Kurichhu, and Tala plants was 5,336 million kWh (PTC India 2010).

\section{Micro-hydropower Plants}

Nepal and Pakistan have rich experience in microhydropower plants (100 kW or less capacity), especially in relation to community involvement in the planning, construction, and operation of such plants (Bhutto and Karim 2007; Clemens, Rijal and Takada 2010). These countries also have a significant industrial base that produces the electro-mechanical equipment necessary for micro-hydropower plants. For example, in the on the loan taken from a US private venture fund to build the power plants. The remainder of the capital investment is being funded by the community (20\%) and the Government of Pakistan through its poverty alleviation fund (50\%) (Hunzai 2011).

\section{Constraints on Development}

The constraints on the development of the small and medium hydroelectric power industry in the region can be categorised as technological, environmental, economic, financial, and institutional (Table 3).

\section{Economic Constraints}

The major economic barrier is the low load factor (i.e., the ratio of average demand over the year to peak demand) on the power plants. This is one of the main factors leading to high tariff rates for consumers in countries with a low industrial base in the region, including Nepal. 


\section{Environmental Constraints}

The consequences of climate change for water resources management has made it even more important to look at constraints related to environmental concerns. In the Himalayan region, this includes adaptation to climate change impacts on river flow variability, sedimentation, and potential GLOF (Glacial Lake Outburst Flood) events, among other things. Bhutan, for example, has identified some major concerns in its National Adaptation Program of Action (NAPA) report (Bhutan NAPA n.d.). to undertake such projects. This is a major concern in India in relation to small power plant construction, despite its well-developed construction industry. At the operational stage, the main constraint is lack of mechanisms for transmission and distribution, such as wheeling facilities, a concern often raised by independent power producers in the region, and a lack of mechanisms to prevent non-technical system losses, such as theft during distribution, which is a major problem in India and Nepal.

While it is important to find solutions to all

\begin{tabular}{|c|c|c|c|c|c|}
\hline & \multicolumn{5}{|c|}{ CONSTRAINTS } \\
\hline Country & Economic & Environmental & Technological & Financial & Institutional \\
\hline Bhutan: & & $\begin{array}{l}\text { GLOFs*; river flow } \\
\text { variability }\end{array}$ & & & \\
\hline China: & & & $\begin{array}{l}\text { Hydropower resources far } \\
\text { from consumption centres }\end{array}$ & $\begin{array}{l}\text { Long pay-back } \\
\text { period; difficult to } \\
\text { raise funds }\end{array}$ & \\
\hline India: & $\begin{array}{l}\text { Low load } \\
\text { factor }\end{array}$ & & $\begin{array}{l}\text { Scaled down technology } \\
\text { not appropriate for small } \\
\text { plants }\end{array}$ & & $\begin{array}{l}\text { High construction } \\
\text { costs; lack of } \\
\text { technical expertise } \\
\text { and experienced local } \\
\text { contractors }\end{array}$ \\
\hline Nepal: & $\begin{array}{l}\text { Low load } \\
\text { factor }\end{array}$ & $\begin{array}{l}\text { GLOFs; river } \\
\text { flow variability; } \\
\text { sedimentation }\end{array}$ & $\begin{array}{l}\text { High cost of development; } \\
\text { lack of domestic electro- } \\
\text { mechanical equipment } \\
\text { manufacturing capability; } \\
\text { access to potential sites }\end{array}$ & $\begin{array}{l}\text { Difficult to raise } \\
\text { funds }\end{array}$ & $\begin{array}{l}\text { Domestic construction } \\
\text { industry capacity; } \\
\text { wheeling facilities; } \\
\text { community participation; } \\
\text { high system losses }\end{array}$ \\
\hline Pakistan: & & Sedimentation & & & \\
\hline
\end{tabular}

Table 3. Some constraints on the development of small hydropower in the HKH region (sources: Bhutan: NAPA Report 200; China: Jiang 2006; India: Metri 2005; Nepal: WECS 2002; Pakistan: Ali and Ibash 2005)

\section{Technological Constraints}

The major technological constraint is the transmission and distribution networks. The networks could be for the delivery of electricity to users in isolated systems or for connecting the power generated with grid-networks. This has caused problems in China, for example, where hydropower resources are far from the consumption centres.

\section{Financial Constraints}

The major financial constraint is difficulty in raising funds from capital markets at a cost that allows the project to sell power at affordable prices to its consumers. The cost of capital is the return required by investors in the capital market and it depends on the level of risk on investment. Major risks are: production risk, country risk, market risk, and currency risk. The difficulty in raising funds at a reasonable rate to finance small power projects is a major concern, not only in Nepal, where infrastructure finance is at an early stage of development, but also in China, a country with a well-developed infrastructure finance system.

\section{Institutional Constraints}

The major institutional constraint at the development stage is lack of a domestic construction industry able of the major constraints on the development of the hydropower industry, this paper focuses on solutions to some of the environmental and financial constraints. This sub-section looks at the crafting of institutional mechanisms on the basis of concrete financial transactions for payment for environmental services (PES), drawing on the case of the Catskills' watersheds in New York and the Kulekhani watershed in Nepal. It is followed by discussions on the potential to raise partial funds for hydropower development from the carbon finance available for emissions reduction under the Clean Development Mechanism.

\section{Concrete Financial Transactions for PES}

The value of a single ecosystem service such as sedimentation control can be determined using the replacement cost method. The replacement cost compares the cost of providing the service through an ecosystem with an alternative method. The difference in these costs is the value of the ecosystem service. The Catskills' watershed is a useful example of the application of this method.

The Catskills' watersheds have historically supplied New York City with high quality water through a natural filtration process. By 1996, however, development and pollution had started to affect the water quality. The 
cost of building a filtration system was estimated at US $\$ 6$ to $\$ 8$ billion. Alternatively, the cost of protecting and restoring the natural ecosystem processes in the watershed was estimated at US $\$ 1$ to $\$ 1.5$ billion. New York City chose to protect the Catskills' watersheds rather than build a new water filtration system, thus preserving the clean drinking water service provided by the Catskills. The cost of the water filtration plant less the cost of protecting and restoring the watershed was a used as a measure of the value of the ecosystem service of the watershed as a water purification tool (Heal and Barbier 2006; also see NRC 2005 and Pires 2004).

It may be possible to use this methodology to determine the value of watershed conservation in controlling sedimentation in hydropower plants, thereby reducing repair and maintenance costs for turbines and, in the case of storage projects, preserving the storage capacity of the reservoir. Let's take the Kulekhani Hydropower Plant in Nepal is an example.

The Kulekhani River is dammed by a $114 \mathrm{~m}$ dam creating a $2.2 \mathrm{~km}^{2}$ reservoir. The catchment area of the Kulekhani watershed at the reservoir is about $125 \mathrm{~km}^{2}$. The soil erosion rate in the watershed varies according to land use patterns; it is substantially higher for agricultural land than for forest land (Amatya 2004). In the late 1970 s and early 1980 s, the watershed suffered massive deforestation due to the construction of the Kulekhani hydropower plant. Conservation projects helped to form community forestry groups, supported programs on conservation education, and promoted terracing and cultivation in marginal lands. But the major positive change in land use patterns was more by accident than by design. A devastating flood in 1993 washed away agricultural land, which was gradually converted to forest land. As a result, sedimentation in the reservoir declined significantly, and the total reservoir capacity stabilised at around 62 million cubic metres, after having declined from 85.3 million cubic metres in 1982 to 63.8 million cubic metres in 1995 (Upadhyaya 2005). The change in the land use pattern in the Kulekhani watershed following the flood helped to control sediment deposits and stabilise the storage reservoir capacity of the Kulekhani hydropower plant.

A mechanism for the transfer of funds to the community from the hydropower plant operator already exists for the Kulekhani hydropower plant, although it is not based on a valuation of ecosystem services. The Government transfers $12 \%$ of the royalties generated by the Kulekhani Hydropower Plant to the district where the plant is located (Makwanpur District Development Committee); these royalties are then split between the Village Development Committees (VDCs) in the District (50\%), upstream settlements (20\%), downstream settlements (15\%), and the VDCs that house the power plant, generator, dam, and reservoir (15\%) (Karky and Joshi 2009).

As an alternative basis for the sharing of royalties, an analytic framework for the payment for environmental services could be developed based on the valuation of ecosystem services, as in the Catskills' watersheds, but focusing on sedimentation control as opposed to water purification as the regulating service of the ecosystem. This would incentivise upstream communities to conserve forest land, thereby reducing sedimentation rates and maintaining the reservoir's storage capacity. To this end, the existing institutional mechanism used by the Government of Nepal is a step in the right direction; it could be used as the basis for crafting a mechanism for upstream-downstream linkages based on concrete financial transactions as the solution to the environmental constraints on the development of hydropower in the HKH region.

Such a mechanism based on PES may also be valuable in the context of water storage capacity to increase water availability by transforming natural systems from passive to planned, active sources of water storage.

\section{Exploring Carbon Finance to Partially Fund Hydropower Projects}

The main purpose behind the three Kyoto flexible mechanisms - emissionstrading, theClean Development Mechanism (CDM), and Joint Implementation (JD) is to help signatories to the Kyoto Protocol to achieve their emission reduction goals by 2008-2012. The CDM has twin objectives: assisting non-Annex I (nonindustrialised and developing) countries in achieving sustainable development; and assisting Annex I (industrialised and developed) countries in achieving compliance with their quantified emission limitation and reduction commitments. Carbon finance is the financial resource provided to projects generating, or expected to generate, greenhouse gas emission reductions in the form of the purchase of such reductions (World Bank 2008).

Hydropower projects are expected to contribute substantially to the potential 2012 supply of Certified Emission Reductions (CERs). The volume transacted from clean energy projects reached 358 million tonnes of carbon dioxide equivalent $\left(\mathrm{MtCO}_{2} \mathrm{e}\right)$ in 2007 and occupied a $64 \%$ share of the $\mathrm{CDM}$ project market, including a $12 \%$ market share of hydropower (World Bank 2008) (Figure 2). It is expected that about 20\% of the CERs issued will be related to hydropower by the end of 2012 (Liu and Hu 2011). At the end of March 2008, there were 3,188 projects in the CDM pipeline: 978 registered projects, 188 in the process of registration, and 2,022 at the validation stage (World Bank 2008). As at July 2010, there were 5,312 Clean Development Mechanism projects globally, at different stages of processing, $27 \%$ of which $(1,454)$ are hydropower projects (Liu and $\mathrm{Hu}$ 2011). The two countries with the largest number of CDM hydropower projects in the list - China and India - are in the HKH region. China has almost two-third of all the hydropower CDM projects, which account for $61 \%$ of the expected total capacity, followed by India with $12 \%$ of the total capacity (Table 4).

Although carbon finance may be a good source of funding for small and medium hydropower projects, there are a number of hurdles to overcome. The greenhouse gas emission reductions generated by $\mathrm{CDM}$ project activities must be additional to those that 
would otherwise occur. This additionality criterion is established when there is a positive difference between the emissions that occur in the baseline scenario and the emissions that occur in the proposed project (World Bank 2008).

\section{Knowledge Gaps and Institutional Capacity Building Needs}

The following knowledge gaps and institutional reforms are needed for hydropower development in the $\mathrm{HKH}$ region:

\section{Valuation of Water-related Ecosystem Services in} Mountain Systems

Mechanisms for upstream-downstream linkages need to be supported by concrete financial transactions, and these need to be based on the valuation of water-related ecosystem services. There is a need for improved documentation of the potential of various ecosystems to provide goods and services, and of the effect of changes in ecosystem structure and functions on the provision of these goods and services; for increased collaboration among ecologists and economists in valuing ecosystem goods and services; for improvements in study design and validity tests for stated-preference methods of nonmarket valuation; and for valuation methods based on integrated ecological-economic systems (NRC 2005). It is also important to effect improvements in the methodology used to value mountain ecosystem services to address the challenges of bio-physical characteristics such as high altitude, slope, and large variations in temperature and moisture, which result in a high degree of heterogeneity (ICIMOD 2011).

Additionality Criteria for Carbon Financing of Hydropower Projects.

As mentioned earlier, the CDM has the two objectives of assisting non-Annex I countries in achieving sustainable development, and assisting

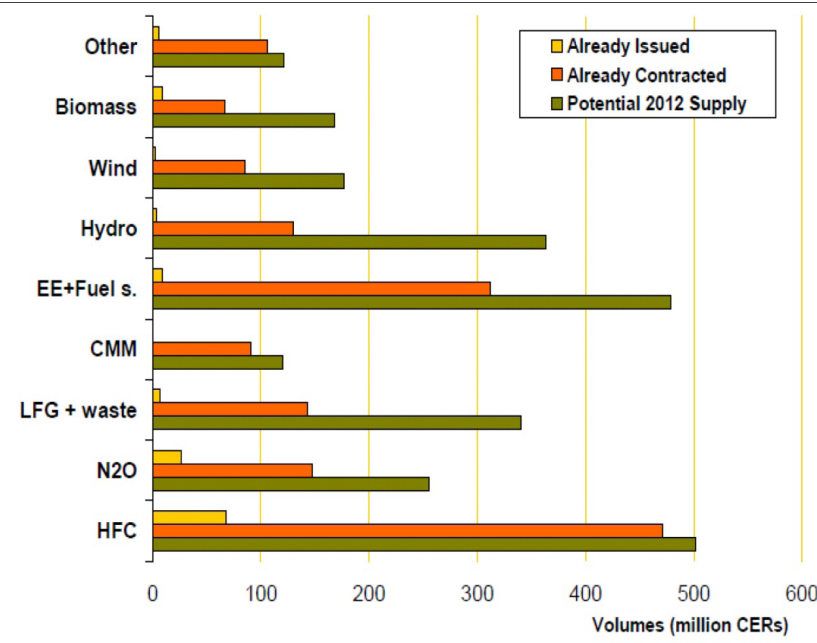

Figure 2. Certified Emission Reductions, potential supply to 2012 (source: World Bank 2008)

\begin{tabular}{|l|c|c|c|}
\hline \multicolumn{1}{|c|}{ CoUNTRY } & $\begin{array}{c}\text { Number of } \\
\text { Hydroproject } \\
\text { Projects }\end{array}$ & $\begin{array}{c}\text { Installed } \\
\text { Capacity, } \\
\text { When } \\
\text { Completed } \\
\text { (MW) }\end{array}$ & $\begin{array}{c}\text { Installed } \\
\text { Capacity } \\
\text { (\% of total) }\end{array}$ \\
\hline China & 934 & 32,258 & 61 \\
\hline India & 152 & 6,409 & 12 \\
\hline Brazil & 85 & 3,974 & 7 \\
\hline Peru & 23 & 1,402 & 3 \\
\hline Bhutan & 3 & 1,134 & 2 \\
\hline Other countries & 257 & 7,867 & 15 \\
\hline \multicolumn{1}{|c|}{ Total } & $\mathbf{1 , 4 5 4}$ & $\mathbf{5 3 , 0 4 4}$ & $\mathbf{1 0 0}$ \\
\hline
\end{tabular}

Table 4. Hydropower CDM Projects in the Pipeline (1 July 2010) (source: Liu and Hu 2011)

Annex I countries in achieving compliance with their commitments.

The literature suggests that the methodology behind the CDM additionality criteria should be developed to address the following issues:

- The transaction costs of CDM can be high because of the requirement to show that the project will reduce emissions above and beyond the business-asusual scenario, which inevitably involves speculation about what would have happened in the absence of the project (Hepburn 2007).

- Because of the high transaction costs of additionality criteria, the countries with relatively high greenhouse gas emissions dominate the CDM carbon market as sellers of carbon credits (World Bank 2008). As a result, the CDM has a limited role in green growth and sustainable development in non-industrialised countries. It also does little to benefit mountainous countries, such as those in the HKH region, where hydropower is the main source of energy and it is difficult to prove additionality. Furthermore, the financial additionality criterion can be met more readily by projects funded by private capital, compared to those funded by the government, because funding for CDM projects should be "additional to official development assistance" (Spalding-Fecher 2002, in Gautam and Karki 2004). This may be a handicap to countries where private financing of hydropower is at an early stage of development.

Further development of the methodology for assessing additionality would help $\mathrm{HKH}$ countries to raise carbon finance for hydropower development.

\section{Conclusions}

The HKH mountain systems provide vital freshwater services for energy security. The geopolitics of the region and the financing challenges of large multi-purpose projects may, however, delay the development of large storage reservoirs for many years to come. It is necessary, therefore, to increase the pace of hydropower development through small and mediumsized projects. China is a best practice example in small hydropower development. But it is necessary to study 
the conditions behind this success - notably the high level of electricity consumption in industrial activities in rural areas, which has certainly helped to reach a high level of capacity utilization in those plants, and thus a high load factor. As a result, electricity became available at affordable prices for all uses, domestic as well as industrial.

Besides the economic constraints, there are also environmental, technological, financial, and institutional constraints to be addressed. This paper has addressed partial solutions to two of these types of constraint. To address the environmental constraints, institutional mechanisms of upstreamdownstream linkages through payment for ecosystem services based on concrete financial transactions are needed. Improvements in the valuation methodology for mountain ecosystem services will certainly help in developing the basis for such mechanisms to work.

To address the financial constraints, carbon finance available through the CDM may help to some extent. The additionality criteria, however, still asymmetrically favor developing countries with relatively high greenhouse gas emissions. Especially in the mountain regions, where hydropower is the main source of energy, it is difficult to meet the criteria to prove additionality. The methodology for assessing additionality requirements needs to be revisited from the perspective of the CDM's objective of promoting sustainable development of developing countries, and especially from the perspective of sustainable mountain development.

For the past five decades, national governments, the private sector, academia, and civil society in the $\mathrm{HKH}$ region have highlighted in their plans, policies, and discussions the role of water and hydropower in the sustainable development of the region. It is hoped that the challenges that climate change poses to mountains and water, the gradual acceptance by stakeholders of the need to establish linkages between upstream and downstream communities for better water management, and the new perspective of green growth and sustainable development can help to translate those plans and policies into reality.

\section{Acknowledgements}

I am grateful to Dr. Andreas Schild, the then Director General of ICIMOD, for encouraging me to write this paper and for his valuable comments and suggestions on an earlier draft. I am also thankful to Dr. Madhav Karki, Deputy Director General of ICIMOD, and Dr. Golam Rasul, Head of the Economic Analysis Division, for their insightful comments and suggestions. I am much obliged to Dr. Bhaskar Singh Karky and Dr. Amina Maharjan of the same division for their valuable comments and suggestions on the technical aspects of the paper.

This paper was presented at the session on
'Mountain Ecosystem Services: Scope, Opportunities and Challenges in the Context of the Green Economy' at the International Conference on Green Economy and Sustainable Mountain Development: Opportunities and Challenges in View of Rio+2O, Kathmandu, Nepal, 5-7 September 2011.

Dr. Ramesh Vaidya, is Senior Advisor at ICIMOD (International Centre for Integrated Mountain Development), an inter-governmental organization of eight countries in the Hindu Kush-Himalaya Region. Earlier, he served as National Planning Commission member for Water, Energy and Infrastructure. During his tenure in the Planning Commission, the Alternative Energy Promotion Centre (1996) was established and he served as its first Vice-Chairman on the Board. The Hydropower Development Policy of Nepal (2001) and the Water Resources Strategy of Nepal (2002) were also prepared during his tenure in the Planning Commission. Dr. Vaidya has represented Nepal in several international water and energy events, including the UN Commission on Sustainable Development meetings.

Corresponding address: rvaidya@icimod.org

\section{References}

ADB (Asian Development Bank), 2009, Basic Statistics, Available from: data.worldbank.org/indicators

Ali, I. and Q. Ibash, 2005, Water and Energy, World Bank Country Water Resources Assistance Strategy Background Paper \#4, March 2001, Washington DC: The World Bank (unpublished).

Amatya, U.B., 2004, Rain-Storm Induced Soil Erosion in Kulekhani Watershed and Inflow Analysis in the Kulekhani Reservoir, RUPES (Rewarding the Upland Poor for Environmental Services) Kulekhani Program Study Report, Kathmandu: Winrock International.

Bhutan NAPA (National Adaptation Program of Action), n.d., Report Prepared by the National Environment Commission of the Royal Government of Bhutan with Support from UNDP and GEF, Thimphu: National Environment Commission.

Bhutto, A.W. and Karim, S., 2007, 'Energy-poverty alleviation in Pakistan through use of indigenous energy resources', Energy for Sustainable Development 11(1):58-67.

CEA (Central Electricity Authority), 2008, India, Available from http://cea.nic.in/hydro/.

Clemens, E., K. Rijal and M. Takada, 2010, Capacity Development for scaling Up Decentralized Energy Access Programs: Lessons from Nepal on its Role, Costs, and Financing, Warwickshire, UK and New York: Practical Action Publishing Ltd and United Nations Development Program.

Dyurgerov, M.D and M.F. Meier, 2005, Glaciers and Changing Earth System: A 2004 Snapshot, Boulder: Institute of Arctic and Alpine Research, University of Colorado. 
Economist, 2010, "For want of a drink", A special report on water', The Economist, 22 May 2010.

Gautam, U. and A. Karki, 2004, Hydropower Pricing in Nepal, Kathmandu: Jalsrot Vikas Sanstha.

Heal, G.M. and E.B. Barbier, 2006, 'Valuing ecosystem services', Economists' Voice, Berkeley: Berkeley Electronic Press.

Hepburn, C (2007) 'Carbon trading: A review of the Kyoto mechanisms'. Annual Review of Environment and Resources 32: 375-393

Hunzai, I.A., 2011, 'Renewable energy development through community ownership and management in the remote mountain valleys of Northern Pakistan', Case Study Presentation at the ICIMOD Regional Sharing Workshop on Assessment of Challenges and Opportunities in the Asia-Pacific Region for Rio+20, Kathmandu, 23-25 August.

ICIMOD, 1994, Mini- and Micro-Hydropower for Mountain Development in the Hindu-Kush Himalayan Region, A report of the International Experts' Consultative Meeting, Kathmandu, Nepal, 13-17 June, International Center for Integrated Mountain Development.

ICIMOD, 2011, Framework for Valuing of Ecosystem Services in the Himalayas, ICIMOD Technical Report prepared by G. Rasul, N. Chettri, and E. Sharma, Kathmandu: International Center for Integrated Mountain Development.

Immerzeel, W.W., L.P.H. van Beek, and M.F.P. Bierkens, 2010, 'Climate change will affect the Asian water towers', Science 328:1382-1385.

IPCC, 2007, Climate Change 2007: Impacts, Adaptation and Vulnerability, Contribution of Working Group II to the Fourth Assessment Report of the Intergovernmental Panel on Climate Change, Cambridge, UK and New York, USA, Cambridge, UK: Cambridge University Press.

Jiang Kejun, 2006, 'Management of energy resources in China', Paper presented by the China Energy Research Institute at the Annual Bank Conference in Development Economics, Tokyo, Japan, 29-30 May.

Karky, B. and S.L. Joshi, 2009, 'Payment for environmental services: An approach to enhancing water storage capacity', Sustainable Mountain Development, 56:27-30.

Liu, H. and X. Hu, 2011, 'The development and practice of small hydropower clean development mechanism projects in China', HydroNepal: Journal of Water, Energy and Environment 8:8-13.

MA (Millennium Ecosystem Assessment), 2005, 'Ecosystems and human Well-Being: Current State and Trends', v.1, pp.25-36, Washington DC: Island Press.

Metri, B.A., 2005, 'Benchmarking small hydro industry in India: A road to superior performance', Energy for Sustainable Development 9(4):68-72.

National Bureau of Statistics of China (2006) China Statistical Yearbook 2006.
NEA, 2010, Fiscal Year 2009-2010: A Year in Review, Kathmandu: Nepal Electricity Authority.

NRC, 2005, Valuing Ecosystem Services: Toward Better Environmental Decision-Making, Washington DC: National Academy Press for the National Research Council of the National Academy of Sciences, Committee on Assessing and Valuing the Services of Aquatic and Related Terrestrial Ecosystems.

Pires, M., 2004, 'Watershed protection for a world city:

The case of New York', Land Use Policy 21:161-175.

PTC India, 2010, Eleventh Annual Report 2009-2010, New Delhi: Power Trading Corporation India Limited.

Sen, S., 2006, 'Grid interconnections and issues', Presentation by the Power Grid Corporation of India Ltd. at the Power Summit organized by the Independent Power Producers Association of Nepal and PTC India Limited, in Kathmandu, Nepal.

Spalding-Fecher, R. (ed.), 2002, The CDM Guidebook, Cape Town: Energy and Development Research Center.

Tyndall Centre for Climate Change Research data 2005: Mitchell, TD; Hulme, M: New, M (2002) Climate Data for Political Areas. Area 34. 109-112.

UN General Assembly Statement of Nepal, 1998, Statement by Honourable Madame Shailaja Acharya, Deputy Prime Minister and the Head of the Delegation of Nepal to the General Assembly Meeting, New York, USA.

UNEP, 2011, Towards a Green Economy: Pathways to Sustainable Development and Poverty Eradication, Nairobi: United Nations Environment Program.

Upadhyaya, S.K., 2005, Payments for Environmental Services: Sharing Hydropower Benefits with Upland Communities, RUPES (Rewarding the Upland Poor for Environmental Services) Kulekhani Working Paper 1, Kathmandu: Winrock International.

Vorosmarty, C.J., P. Green, J. Salisbury and R.B. Lammers, 2000, 'Global water resources: Vulnerability from climate change and population growth', Science 289:284-288.

WECS, 2002, Water Resources Strategy-Nepal, Kathmandu: Water and Energy Commission Secretariat

World Bank, 2008, State and Trends of the Carbon Market 2008, Washington DC: The World Bank.

World Resource Institute (WRI); http://earthtrends. wri.org/ 